\title{
Spatial Modeling of the Effects of Deflation Destruction of the Steppe Soils of Ukraine
}

\author{
Nataliia Vasylivna Dudiak', Vitalii Ivanovich Pichura ${ }^{1 *}$, Larisa Aleksandrovna \\ Potravka ${ }^{1}$, Alexander Alexandrovich Stroganov ${ }^{1}$
}

${ }^{1}$ Kherson State Agricultural University, Stritens'ka str. 23, 73006, Kherson, Ukraine

* Corresponding author's e-mail: pichuravitalii@gmail.com

\begin{abstract}
The decrease in the agricultural efficiency is associated with the influence of wind erosion, the consequence of which is a decrease in the soil fertility. Significant effects of wind erosion are typical of the arid and semi arid zones with a small amount of precipitation, high air temperature and degree of evaporation, reinforced by strong winds and low differentiation of plant protection. It has been proven that the intensity of the effects of deflation processes depends on the physical and geographical conditions of the distribution of agricultural land, systematic soil protection activities and the availability of vegetation. It has been established that the acceleration of the deflation processes occurs in the territories with increased anthropogenic pressure, which leads to ecological disturbance of the natural balance characterizing territorial ecosystems. In the course of the studies it was found that the natural processes of wind erosion are significantly enhanced by the absence of a scientifically-based and ecological land development system of agriculture, which leads to destruction of the soil cover, reduction of soil fertility, damage to the agricultural crops and, thus, the economic damage. As a result of application of the GIS and ERS technologies, the empirical-statistical model of the possible soil loss due to wind erosion in the territory of the Steppe zone of Ukraine, it has been found that in the course of the deflation processes in the territory taken by naked fallow upon the absence of the conditions for the deflation resistance activities, the value of soil loss at the epicenter of dust storms can reach about $600 \mathrm{t} / \mathrm{ha}$. Studies proved the importance of the deflation resistant action of the vegetation cover, which tends to an increase in the erosion dangerous (favorable) areas of agricultural land by 1.7 times, which reduces the soil loss by 5.62 times. In accordance with the intensity of the effects of the deflation processes and the increase of the soil losses, the contour and land development deflation resistance activities with elements of soil protection agriculture were proposed.
\end{abstract}

Keywords: wind erosion, soil loss, steppe soils, geomodeling, GIS technologies, ERS

\section{INTRODUCTION}

The expansion of the zone of influence of wind erosion leads to a decrease in the efficiency of agriculture, since the deflation-spatial redistribution of the soil particles reduces the level of soil fertility, which is the main factor influencing the crop yields. It was proven (Lysetsky et al., 2012) that the intensity of effect of deflationary processes depends on the physical and geographical conditions of the distribution of agricultural land, systematic soil protection measures and the availability of the vegetation cover. Significant effects of wind erosion are typical of the arid and semi arid zones, with a small amount of precipitation, high air temperature and degree of evaporation, reinforced by strong winds and low differentiation of vegetation protection. It was established (Pichura et al., 2016, 2017; Dudiak et al., 2019) that the acceleration of the deflation processes occurs in the territories with increased anthropogenic stress, which leads to an ecological disturbance of the natural balance of territorial ecosystems. Scientists note (Achasov et al., 2000; Tarariko et al., 2002; Lysetskyi et al., 2012, 2014; Pichura et al., 2016, 2017; Guo et al., 2019; Jiang et al., 
2019; Pichura et al., 2019) the relevance of studying the factors and processes of wind erosion, the frequency of its effect, heterogeneity of the spatial distribution and economic consequences in recent decades as a necessary condition for ensuring sustainable land use.

It should be noted that an increase in the amplitude of fluctuations in air and soil temperature, a decrease in the amount of annual precipitation (Lysetskyi et al., 2016; Pichura, 2017), hydrothermal coefficient, a reduction in the frost free period and an increase in wind activity lead to the development of deflation processes, determined by the effects of climate characterized by danger of erosion (Shakhaev, 2004), which is determined by continentality. First of all, the steppe zone soils are under the risk of wind erosion processes that are characterized by light particle size distribution, low soil formation rate, average and low humus content, weak cohesion and strength of the soil clods. The main factors of the degree of effects of deflation destruction of the soil cover (Mozheiko et al., 1980; Baliuk et al., 2010; Luo W. et al., 2019; Chi et al., 2019; Sameni et al., 2019) are the characteristics of the wind (speed, repetition rate, its strength and duration), the Earth's surface (vegetation, its height and density of cover, surface roughness, the availability of soil moisture), soils (size of particles, their connectivity, distribution of aggregates and the amount of organic matter). It was proven (Voloshchuk, 2016) that the deflation losses of $10 \mathrm{~cm}$ of the fertile soil layer are equated to the displacement of more than 1 thousand tons / ha of soil, and if the average high degree of erosion is determined, they have lands with a loss of up to 5 thousand tons / ha of soil. The humus storage is $216 \mathrm{t} /$ ha in full-profile chernozems; as a result of erosion, the losses reach $114 \mathrm{t} / \mathrm{ha}$.

The influence of the effects of wind erosion processes in the steppe zone of Ukraine on the efficiency of agriculture emphasizes the need for modeling spatial differentiation and predicting potential soil losses due to erosion. Today, a functioning system for predicting the potential soil losses due to erosion requires creation of spatial models of deflation soil loss, which are the basis for determining the adaptive erosion resistance, soil protective and contour and land development activities. It is necessary to apply the geostatistical and mathematical models with elements of remote sensing of the Earth.
The purpose of the study is the geo-modeling of potential deflation soil losses in the steppe zone of Ukraine, which is aimed at determining the ecological state of agrolandscapes, designing the adaptive complex of erosion resistance, soil protective and contour and land development activities.

\section{MATERIALS AND METHODS}

The possibility of using various approaches for the calculation of deflation soil loss has been analyzed during the study. In particular, Bagnold (1941) proposed an equation for the movement of sand depending on the wind speed over an eroded surface. The modified form of this equation was proposed by Zingg (1953), but it has not been applied further. Chepil (1950) noted that the method proposed by the authors eliminates the spatiotemporal differences of individual factors; therefore, he offered to calculate the potential wind erosion using a method that is similar to the equation for soil loss due to the water erosion processes (Pichura et al., 2016; Dudiak et al., 2019). It is considered that the proposed method is universal, but considering the significant metric differences in the fields, it complicates the process of obtaining an accurate spatial model of the average field length protection, which leads to errors in the calculation of soil losses.

In this regard, the model of wind erosion of the NSC "Institute for Soil Science and Agrochemistry Research named after O.N. Sokolovsky" has been employed in the process of determining the possible soil losses on the territory of the steppe of Ukraine, which has been adapted to various physical and geographical conditions of the country (Mozheiko et al., 1980; Achasov et al., 2000; Bulyhin, 2005):

$$
\mathrm{E}_{\mathrm{r}}=\frac{10^{a-b k} \cdot 0.1 K_{s} \cdot V_{a v_{-} \max }^{3} \cdot t \cdot K_{s p e}}{V_{a e r}^{3}}
$$

where: $E_{r}$ is the potential deflation soil loss, t/ha per year;

$a, b$ are the power coefficients depending on the genesis, granulometric composition, density and other soil properties (calculated experimentally); $k$ is the clodding of the surface $(0-3 \mathrm{~cm})$ soil layer (content of aggregates or particles more than $1 \mathrm{~mm}), \%$; 
$K_{s}$ is the destruction coefficient for aggregates of the surface soil layer under the influence of soil particles and their abrasion by an air-dust flow;

$V_{a v \max }$ is the average maximum wind speed during dust storms of the $20^{\text {th }}$ occurrence, $\mathrm{m} / \mathrm{s}(20 \%$ occurrence shows that this indicator, determined according to multi-year data, is true in 80 cases out of 100 , that is, only in $20 \%$ of cases the wind speed will be higher during dust storms);

$t$ is the average number of hours with the effect of wind erosion per year according to multi-year data;

$K_{\text {spe }}$ is the coefficient of soil protective effectiveness of deflation resistant activities; $V_{\text {aer }}$ is the basic flow velocity in an aerodynamic plant, which is equal to $23 \mathrm{~m} / \mathrm{s}$ in terms of the height of the wind vane $(10 \mathrm{~m}) ; 0,1$ is recalculation from $\mathrm{g} / \mathrm{m}^{2}$ for 5 minutes to t/ha per year.

The calculation of deflation soil losses has been carried out in the GIS environment of the ArcGIS 10.1 licensed software product. Therefore, raster models (cell size $30 \times 30 \mathrm{~m}$ ) of distributions of individual factors in the territory of the steppe zone of Ukraine (Fig. 1) were created, with a total area of 167.4 thousand $\mathrm{km}^{2}$, including agricultural land area -131.6 thousand $\mathrm{km}^{2}$. The agricultural development of the research region varies between $20-97 \%$.

Spatial distribution models of the magnitude of the regression coefficients $(a b)$, clodding $(k)$ and destruction coefficient $(K s)$ were created on the basis of assigning the corresponding values to each soil variety of the steppe zone of Ukraine (Fig. 2). The raster models of spatial distribution of the average maximum wind speed during dust storms $\left(V_{a v \_ \text {max }}\right)$, the average number of hours with the effect of wind erosion per year $(t)$ in the territory of steppe soils were obtained by extrapolating decompositions of data pertaining to the meteorological cartograms for the averaged data from 1990-2018.

The coefficient of soil-protective effectiveness of deflation resistance activities $\left(K_{\text {spe }}\right)$ was calculated using the modified crop erosion index or the vegetation cover coefficient $\left(C^{\prime}\right)$, which reflects the level of crop cultivation efficiency, the influence of the natural vegetation cover (trees, grass) of the land on reducing the soil losses. It was proven that an increase in vegetation leads to a decrease in the soil loss. The land cover

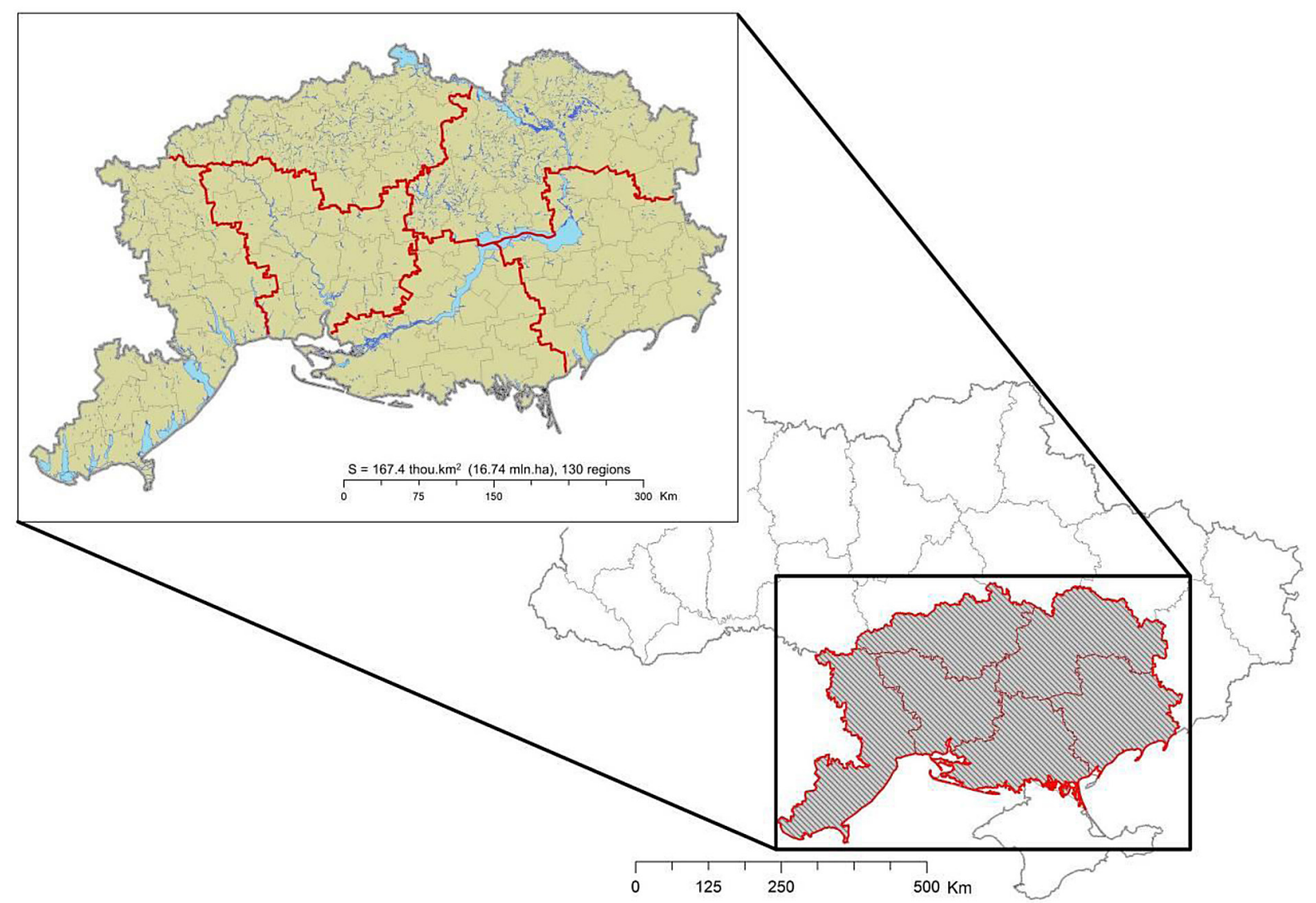

Figure 1. Spatial characteristic of studied territory 

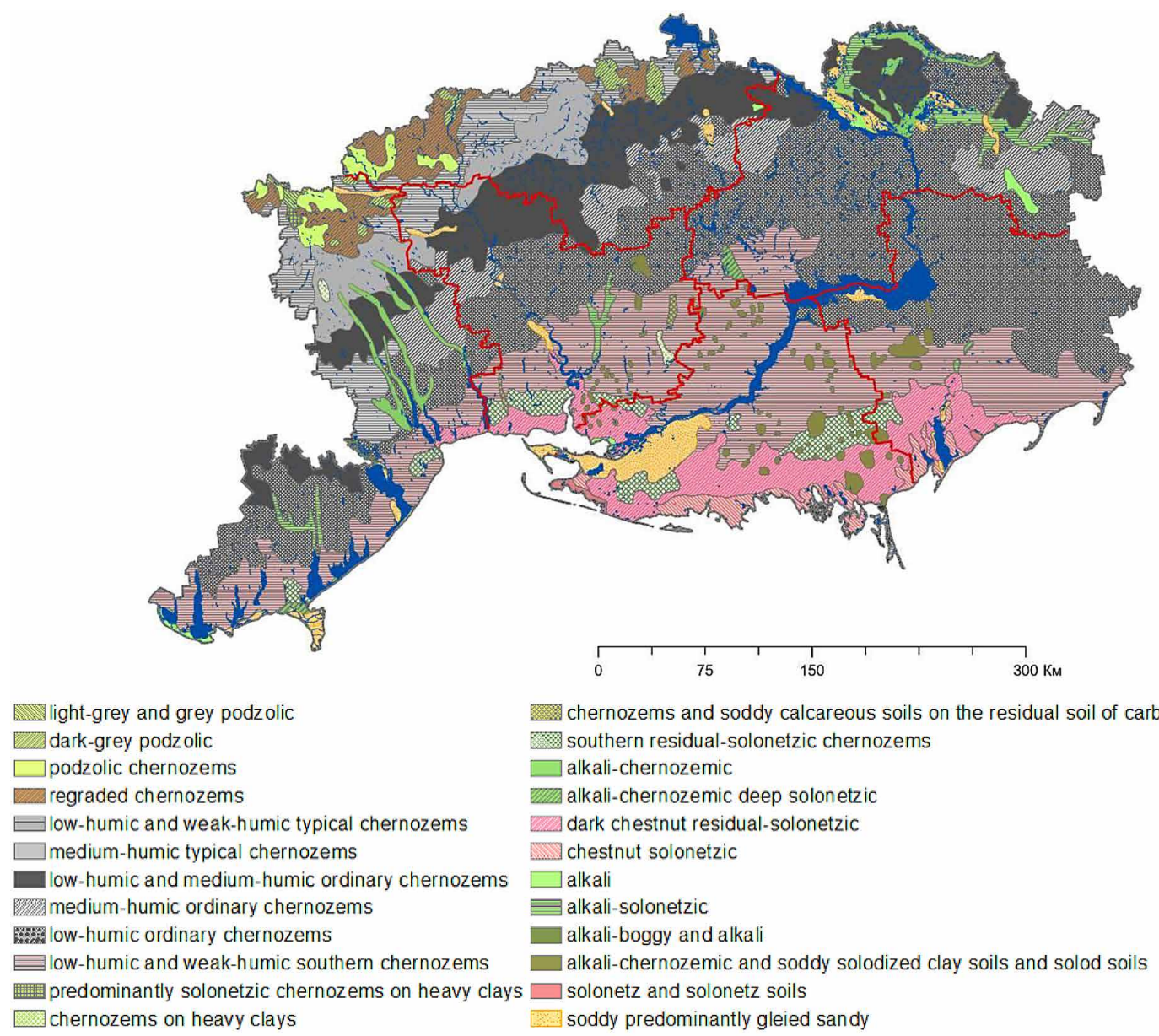

Figure 2. Types of soils in the studied steppe regions

coefficient $\left(\tilde{N}^{\prime}\right)$ is most sensitive to the soil loss (Benkobi et al., 1994; Biesemans et al., 2000).

In order to determine the factor $\tilde{N}^{\prime}$, the authors used the Earth remote sensing (ERS) data of a correctly calibrated satellite image Landsat-8 with a geometric resolution (spatial resolution) of $\sim 30 \times 30 \mathrm{~m}$ as of March and August 2018. The factor values were generated based on the dimensionless indicator NDVI (normalized differential vegetation index); therefore, a modified formula was used (Van Leeuwen et al., 2004):

$$
\begin{gathered}
C=\exp (-\alpha((N D V I) /(\beta-N D V I))) \\
C^{\prime}=C / \max (\mathrm{C})
\end{gathered}
$$

where: $\alpha$ and $\beta$ are dimensionless parameters that determine the shape of the curve, which refers to the NDVI and $C$ factor.

Parameters $\alpha$ and $\beta$ have values 2 and 1, respectively.

The value $C^{\prime}$ ranges from 0 (maximum deflation resistance action of the vegetation cover) to 1 (minimum or absent deflation resistance vegetation).

\section{RESULTS AND DISCUSSION}

In Ukraine, 13.4 million ha of the country territory is under the influence of water erosion, which is $31.4 \%$ of the total area of agricultural land (42.7 million ha). There is 6 million ha under the influence of wind erosion $(14.0 \%$ of the area of agricultural land), and 20 million ha is under the effect of dust storms, where $75 \%$ are low eroded, $25 \%$ are average and highly eroded. The violation of more than 500 thousand hectares of fertile land by the ravines also should be noted. It was determined that over the last 40 years, the area of eroded lands in Ukraine has increased by 2.5 million hectares, with an annual increase of arable land in the amount $60-80$ thousand ha. The soil loss due to erosion is on average 10-15 t/ha per year, and the total average annual soil loss according to various estimates ranges from 260 million tonnes to 500 million tonnes of soil (Shvebs et al., 1985, 2005; Sytnyk et al., 2008; Voloshchuk et al., 2014). In the period of 1960-2015, the area of eroded soils that is taken as agricultural land was increased by $30-35 \%$, the area of 
highly washed away land was increased by $20 \%$, low and average washed away land by 2 and $12 \%$, respectively (Baliuk et al., 2010).

In line with the results of studies, it was determined that Ukraine takes the $9^{\text {th }}$ place among European countries according to the intensity of erosion processes. In particular, together with the products of erosion, 24 million tons of humus, 0.96 million tonnes of nitrogen, 0.68 million tonnes of phosphorus, 9.40 million tonnes of potassium were removed from agricultural land. In this regard, the yield of agricultural crops on eroded soils is being reduced by $20-60 \%$. Therefore, the loss of agricultural production due to erosion exceeds 9-12 million tons of grain per year, and economic losses under such conditions reach 6 billion US dollars (Scientific and applied foundations of soil protection against erosion in Ukraine, 2010).

The reason of negative effects due to erosion is the high degree of ploughing of the territory of Ukraine. More than $80 \%$ of agricultural land has been ploughed, $53.8 \%$ of which is the arable land (Yehoshyn, 1996). In recent years, the land of hydrographic fund, steep slopes, water protection zones, flood meadows and stream beds have been intensively ploughed. The slopes of arable lands are erosion threatened, $80 \%$ of such land belong to low and average erosion threatened, $20 \%$ of the land has increased erosion risk, which requires fundamental changes of the erosion resistance organization of the territory on the basis of soil protective, resource saving, biologically pure, environmentally safe agriculture. An important part of the process optimizing the structure of agricultural landscapes and systems of land use (Furdychko et al., 2012, 2014) is their agroecological typification and zoning according to resource of heat, moisture, soil fertility and risk of erosion effect, which are the main factors of degradation and desertification of agricultural lands.

Researchers established (Chornyi et al., 2007) that the low efficiency of the existing contour and land development deflation resistance activities in the steppe zone of Ukraine caused a large-scale disaster of 2007 , when about $20 \%$ of agricultural land was in the epicenter of the dust storms. In this regard, the soil loss ranged from 10 to 400 tons/ha. Therefore, the matter of soil protection against the degradation processes, especially in the steppe regions of Ukraine, has acquired a special urgency and requires a detailed comprehensive study in the development of the science-based regional soil protective agriculture systems, development of new methods of reproduction of fertility of eroded lands.

With this purpose, as a result of modelling, the raster models of spatial differentiation of wind erosion factors were created and the deflation soil loss in the steppe area of Ukraine was calculated. The regressions coefficients $(a, b)$, clodding coefficients $(k)$, destruction coefficient $\left(K_{s}\right)$ for major soils of Ukraine were calculated in accordance with the method of potential soil loss (Mozheiko et al., 1980; Achasov, et al., 2000; Bulyhin, 2005). It has been determined in the study that the coefficients of the characteristics of genesis, granulometric composition, density and other properties of soils of the steppe region vary for factor- $a$ (Fig. 3a) from 2.3497 (sod-podzolic, soddy podzolized, gleyed, podzolized sandy soils, claysandy and loamy soils) to 4.3060 (chernozems typical and ordinary average- and highly eroded soils) and for factor-b (Fig. 3b) from 0.020 (chernozems southern solonetzic soils) to 0.058 (chernozems typical and ordinary average- and highly eroded soils). The average value of the factor- $k$ (Fig. 3c) vary within $17.5 \%$ (sod-podzolic, sod podzolized, gleyed, sandy podzolic soils, claysandy and sandy loamy soils) $-50.0 \%$ (gray podzolized, podzolized and solonetzic chernozems, chestnut solonetzic, loamy solonetzes and clay soils), factor- $K_{\mathrm{s}}$ (Fig. 3d) - from 0.5 (typical and ordinary chernozems of average and highly eroded soils) to 0.83 (sod-podzolic, soddy podzolized, gleyed, podzolized sandy, clay soils, sandy and sandy loamy soil). The average maximum wind speeds during dust storms of $20 \%$ occurrence $\left(V_{a v \text { max }}\right)$ decrease from the southeastern part of the studied region to the northeast part from 26.1 to $13.7 \mathrm{~m} / \mathrm{s}$. (Fig. 3e). The average number of hours per year involving dust storms $(t)$ in the steppe zone of Ukraine also varies in this direction from 0 to 37.8 hours (Fig. $3 g$ ).

The modified factor $C^{\prime}$ is the erosion index of the crop or the coefficient of vegetation cover, which determines the soil protective effectiveness of the deflation resistant activities $\left(K_{s p e}\right)$ in the steppe soils. This index determines the influence of crop (crop rotation or vegetation cover) and natural vegetation on the deflation processes. In order to establish the influence of the modified factor $C^{\prime}$ on deflation processes, the correctly calibrated satellite image Landsat- 8 was decrypted and the raster model of the spatial distribution of the factor- $C^{\prime}$ on the territory of the studied steppe 

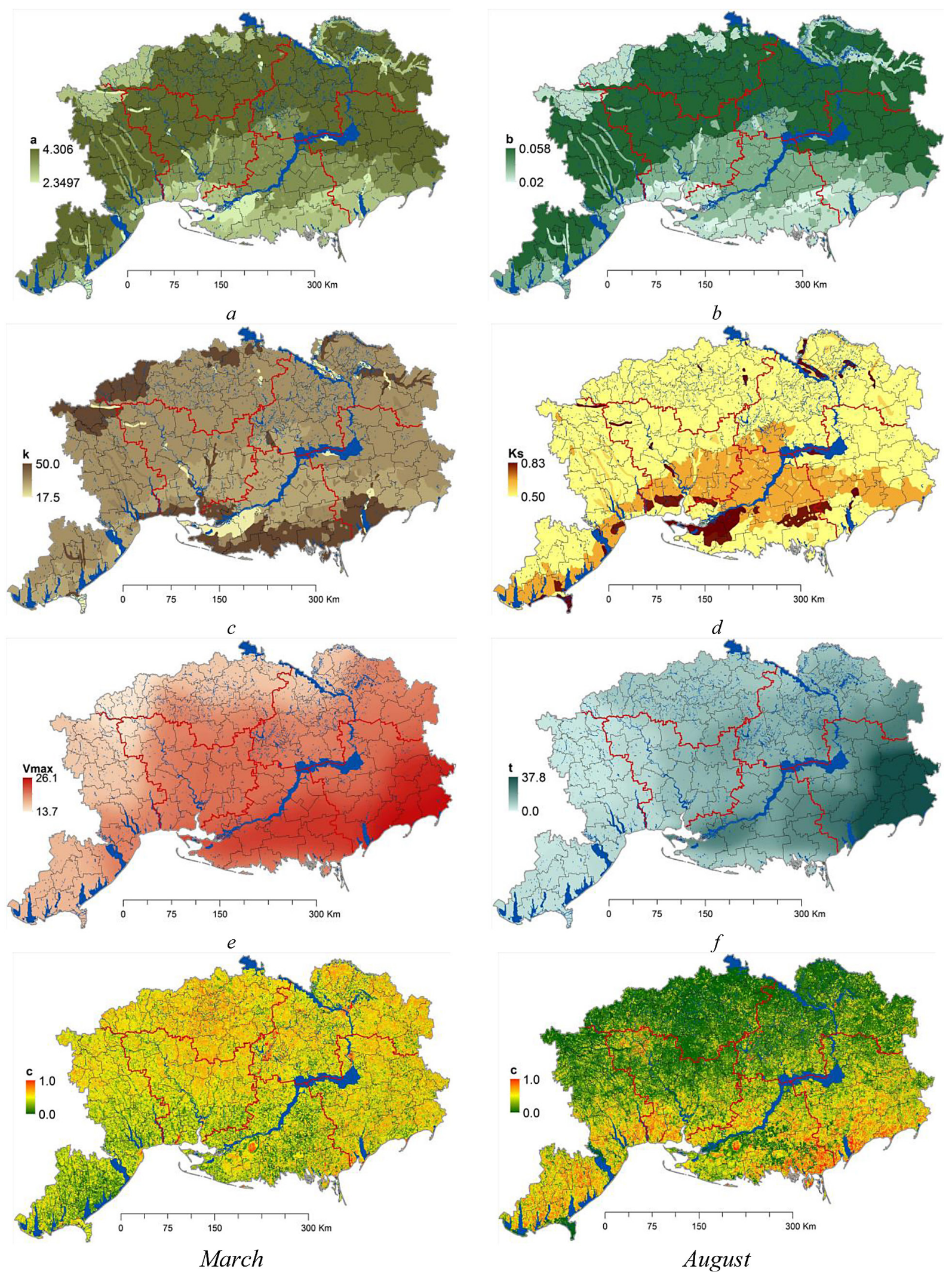

Figure 3. Spatial distribution of factors of the deflation process in the steppe zone of Ukraine: $a, b$ - coefficients that depend on the origin, granulometric composition, density and other soil properties; $c$ - clodding of the surface soil layer, $\% ; d-$ is the destruction coefficient of the aggregates of the surface soil layer; $e-$ is the average maximum wind speed during dust storms of the $20^{\text {th }}$ occurrence, $\mathrm{m} / \mathrm{s} ; f$ - is the average number of hours involving wind erosion effect per year; $g$ - is the coefficient of deflation resistant efficiency of the crop or crop rotation 
region as of March and August 2018 was obtained (Fig.3h). The spatial differentiation of the deflation influence of the factor $C^{\prime}$ depends on the distribution of the land areas taken by the natural vegetation and agricultural crops, and its seasonal value varies from 0 to 1 .

As a result of GIS modeling using the model of possible soil losses as a result of the deflation processes in the area taken by naked fallow, upon the absence of the erosion prevention activities (Fig. 4a), soil losses in the epicenter of dust storms will range from $0.02 \mathrm{t} / \mathrm{ha}$ to $598.3 \mathrm{t} / \mathrm{ha}$. In order to determine the degree of the wind erosion danger for the main soils of the flat territory of Ukraine, the norms of wind erosion processes were considered (Fig. 4b): the erosion rate is $1.5 \mathrm{t} / \mathrm{ha}$ for sod-podzolic: sod and gleyed, their species, sandy and sandy loam; 3.0 t/ha for podzolized soils, gleyed and their regraded species, ordinary chernozems of all kinds; $4.0 \mathrm{t} / \mathrm{ha}$ for typical chernozems of all types, meadow chernozem, meadow and chonozem-meadow soils of all types on loess, alluvial and deluvial rocks; 2.5 t/ha for southern chernozems of all kinds, clay-sandy chernozems, solonetzic chernozems on non-forest rocks; 2.0 for dark chestnut, chestnut solonetzic, meadow chestnut solonetzic, gleyed solonetzic and solodized soils of bottoms, solonetz and solonchaks, meadow marsh, marsh.

There are no deflation losses of soils in the territories (Fig. 4c) without an increase in the normative value thereof (about $11.80 \%$ of the agricultural land area (Table 1)), low erosion is observed in $26.56 \%$ of the area with increased norm of soil losses up to 10 times; the average erosion increased by $10-30$ times with a distribution area of $23.5 \%$ of agricultural land; high erosion increased by 30 to 100 times, the area covers $25.96 \%$; very high erosion increased by 100 to 300 times, about $12.19 \%$ of the land; catastrophic erosion increased by more than 300 times with the possibility of abnormal phenomena effect. In accordance with the increase in the potential soil losses due to deflation processes (Fig. 4d), the introduction of appropriate erosion resistance activities is recommended. In particular, in the territories of the Steppe zone of Ukraine involving a normal (favorable) degree of the wind erosion processes with a permissible increase of soil loss over the erosion rate up to 20 times, the ordinary soil protection activities are to be implemented for $52.61 \%$ of the agricultural land. In the territories with a satisfactory norm increase by 20 to 30 times in $9.24 \%$ of land, it is necessary to carry out additional detailed calculations of the soil loss, introduce minimal or "zero" soil treatment technologies; design the distances between the main forest strips are to be no more than 15-20-multiple heights of plantings.

In the territories with a pre-crisis degree of deflation soil loss (with norm increase by $30-50$ times) in the area of $12.33 \%$ of the land, it is necessary to implement the soil protective systems of soil treatment, carry out additional engineering calculations of the soil losses and calculate the optimal distances between the main forest strips. In the areas with the crisis deflation processes (with norm increase by $50-100$ times), agricultural land area $13.62 \%$, frequency of droughts is 1.5-3.5 years with a hydrothermal coefficient of $0.2-0.3$. The minimum system of soil protective treatment, the obligatory seasonal calculation of the soil loss and adjustment of the optimal distances between forest strips should be carried out. In addition, it is necessary to adjust the ratio of the main agricultural lands; moderate moistening during irrigation is also required. A catastrophic degree of the wind erosion processes is observed in the steppe soils with an area of $12.19 \%$ with increased norms of soil loss by more than 100 times. The frequency of drought occurrence is 1.5-2.0 years with a hydrothermal coefficient of $0.2-0.3$. These territories require scientific justification of soil protective optimization of the structure of areas of the main agricultural land, the introduction of special land development activities, activities against salinization, soil salinization and desertification of territories. As a result of modelling, it was found that reducing the influence of the seasonal danger of wind erosion processes, especially in the period of dust storms, provides a natural vegetation cover and plant cover of agricultural crops (Fig. $4 e, h$ ).

According to the intensity of the effects of the deflation destruction of soils, the agricultural lands in the steppe zone of Ukraine are divided into IV categories of erosion danger, in accordance with which the contour and land development activities were introduced: I category covers the lands that are not subject to wind erosion, soil loss is lower than $6 \mathrm{t} / \mathrm{ha}$; II category covers the lands with low wind erosion, soil loss is 6-10 t/ha; III category covers the lands with an average wind erosion, soil loss is $11-20 \mathrm{t} / \mathrm{ha}$; IV category covers the lands with high wind erosion, soil loss is more than $20 \mathrm{t} / \mathrm{ha}$. The potential soil 

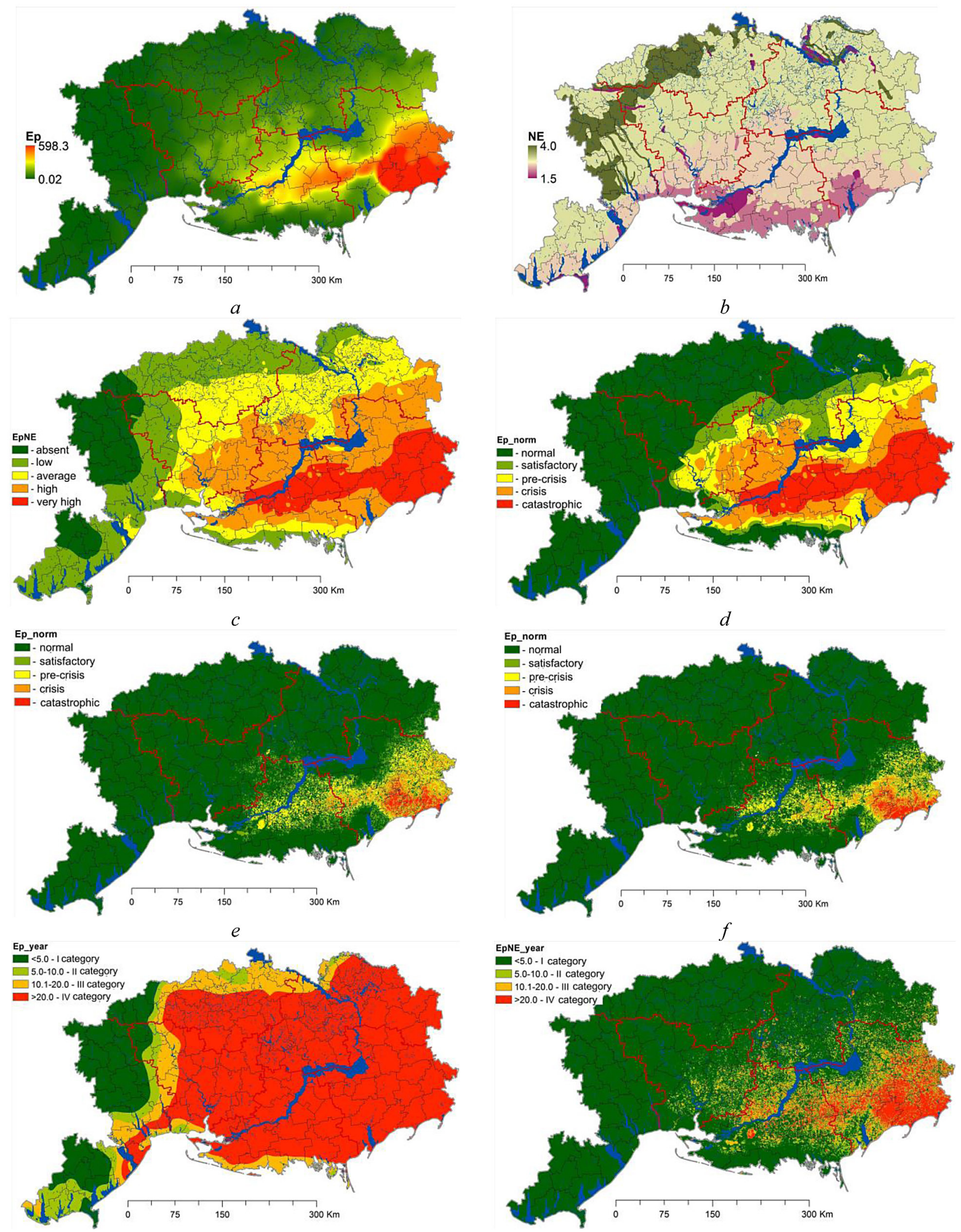

Figure 4. Modeling the spatial distribution of potential deflation soil losses $(\mathrm{t} / \mathrm{ha})$ in the steppe zone of Ukraine: $a$-is the potential deflation soil losses from areas covered by naked fallow; $b$ - is the annual norms of soil erosion; $c$ is the degree of danger of the wind erosion processes with soil differences; $d$ - is the degree of development of the wind erosion processes in accordance with their standards; the degree of seasonal danger of the wind erosion processes, taking into account the c-coefficient: $e$ - is March; $f$-is August; distribution of the territory into categories of deflation soil losses: $g$-upon the absence of deflation resistance activities; $h$ - taking into account the coefficient of deflation resistance in the efficiency of the crop or crop rotation. 
loss in terms of the deflation resistance efficiency of crops or crop rotation (Fig. $4 k$ ) are decreased by 5.62 times in comparison with the model for the lack of the deflation resistance activities (Fig. 4h), which allows to optimize the additional costs for implementing the deflation resistance activities: for the I category of agricultural land with the specific area of $79.64 \%$ it is recommended to use the zonal agricultural activities with the preservation and restoration of shelter belts; for the II category of area $8.38 \%$, it is recommended to implement simple erosion resistance activities - optimal timing of soil treatment, fertilizing, snow retention, no moldboard cultivation and planting with preservation of the stubble on the soil surface, the crop location and fallows with alternating strips of width 100-200 $\mathrm{m}$ and perpendicular to the direction of erosive winds threat, additional creation of shelter belts; for the III category of land with a specific area $6.07 \%$, the same activities as for the land of II category should be carried out, with additional subsurface treatment and sowing with maximum preservation of stubble, creating hedges of tall crops, strip placement of crops and

Table 1. Distribution of arable land according to the degree of danger of wind erosion processes effect

\begin{tabular}{|c|c|c|c|}
\hline $\begin{array}{l}\text { Degree of development of wind } \\
\text { erosion processes }\end{array}$ & $\begin{array}{c}\text { Increase of soil loss above erosion } \\
\text { norm (by times) }\end{array}$ & Area, thous. ha & Specific weight, \% \\
\hline \multicolumn{4}{|c|}{$\begin{array}{c}\text { The degree of danger of wind erosion processes with soil differences from territories taken by naked fallow upon absence of } \\
\text { deflation resistance activities }\end{array}$} \\
\hline Absent & \begin{tabular}{|c|}
$0-1$ \\
\end{tabular} & 1552.7 & 11.80 \\
\hline Low & $1-10$ & 3495.5 & 26.56 \\
\hline Average & $10-30$ & 3092.5 & 23.50 \\
\hline High & $30-100$ & 3416.5 & 25.96 \\
\hline Very high & 100-300 & 1604.8 & 12.19 \\
\hline \multicolumn{4}{|c|}{ The degree of development of wind erosion processes in accordance with their normative losses } \\
\hline Normal (favorable) & $1-20$ & 6924.6 & 52.61 \\
\hline Satisfactory & $20-30$ & 1216.2 & 9.24 \\
\hline Pre-crisis & $30-50$ & 1623.5 & 12.33 \\
\hline Crisis & $50-100$ & 1792.9 & 13.62 \\
\hline Catastrophic & $>100$ & 1604.8 & 12.19 \\
\hline \multicolumn{4}{|c|}{$\begin{array}{c}\text { The degree of seasonal danger of wind erosion processes, taking into account the coefficient of deflation resistance efficiency } \\
\text { of the crop or crop rotation }\end{array}$} \\
\hline \multicolumn{4}{|c|}{ March } \\
\hline Normal (favorable) & $1-20$ & 11404.9 & 86.65 \\
\hline Satisfactory & 20-30 & 664.8 & 5.05 \\
\hline Pre-crisis & $30-50$ & 585.8 & 4.45 \\
\hline Crisis & $50-100$ & 374.4 & 2.84 \\
\hline Catastrophic & $>100$ & 132.1 & 1.00 \\
\hline \multicolumn{4}{|c|}{ August } \\
\hline Normal (favorable) & $1-20$ & 11715.4 & 89.01 \\
\hline Satisfactory & $20-30$ & 535.9 & 4.07 \\
\hline Pre-crisis & $30-50$ & 475.0 & 3.61 \\
\hline Crisis & 50-100 & 303.4 & 2.31 \\
\hline Catastrophic & $>100$ & 132.2 & 1.00 \\
\hline \multicolumn{4}{|c|}{ Territory distribution by categories of deflation soil losses upon absence of deflation resistance activities, $\mathrm{t} / \mathrm{ha}$} \\
\hline I category & $<5.0$ & 1864.6 & 14.17 \\
\hline II category & $5.0-10.0$ & 840.4 & 6.39 \\
\hline III category & $10.1-20.0$ & 1581.5 & 12.02 \\
\hline IV category & $>20.0$ & 8875.4 & 67.43 \\
\hline \multicolumn{4}{|c|}{$\begin{array}{c}\text { Territory distribution by categories of deflation soil losses, taking into account the coefficient of crop deflation resistance } \\
\text { efficiency or crop rotation, } t \text { / ha }\end{array}$} \\
\hline I category & $<5.0$ & 10482.4 & 79.64 \\
\hline II category & $5.0-10.0$ & 1102.8 & 8.38 \\
\hline III category & $10.1-20.0$ & 798.9 & 6.07 \\
\hline IV category & $>20.0$ & 777.9 & 5.91 \\
\hline & Total: & 13162 & 100 \\
\hline
\end{tabular}


fallows in combination with buffer strips of perennial grasses, and the establishment of a system of shelter belts; for the land of IV category with area of $5.91 \%$, it is recommended to implement the entire complex of erosion resistance measures, including the introduction of soil-protective crop rotations with a dominant share perennial grasses in the crop rotation, subsurface treatment and sowing with maximum preservation of stubble on the soil surface, solid grassing of wind breaking slopes, placement of crops, fallows and buffer strips with perennial grasses in strips of a width of 50-100 m, perpendicular to the direction of erosive winds threat, the creation of a dense network of forest strips.

In order to reduce the impact of rising temperatures, droughts, water and wind erosion, it is necessary to develop and gradually implement the erosion resistance soil protective activities aimed at the rational use of resources of moisture. The basis of the erosion resistance system is a contour arrangement of the territory of agricultural land, which is differentiated according to the topography of arable land, the use of hydrotechnical, forests and meadow land development and the achievement of humus balance as a result of the adjustment of crop rotation. In this context, it is necessary to introduce a contour and land development organization of the territory subject to the implementation of the principles of land and water use (Lysetskyi et al., 2014; Dehodiuk 2015), which provides the development of appropriate national and regional programs of soil protection against erosion, degradation and desertification, as well as adaptation of land use to new climatic conditions.

\section{CONCLUSIONS}

As a result of the application of the GIS and ERS technologies, the empirical-statistical model of possible soil loss due to the wind erosion in the territory of the Steppe zone of Ukraine, it was found that as a result of the deflation processes in the territory taken by naked fallow upon the absence of the conditions for the deflation resistance activities, the value of soil loss at the epicenter of dust storms can reach about $600 \mathrm{t} / \mathrm{ha}$. According to the norms of soil differences, about $40 \%$ of agricultural land is characterized by high and very high effect of deflation processes. Studies proved the importance of the deflation resistant action of the vegetation cover, which tends to an increase in the erosion dangerous (favorable) areas of agricultural land by 1.7 times, which reduces the soil loss by 5.62 times. In accordance with the intensity of the effects of deflation processes and the increase of soil losses, contour and land development, the deflation resistance activities with elements of soil protection agriculture were proposed. Attention was focused on the importance of introducing a scientifically-based, ecological and land development system of agriculture, since its absence contributes to the negative consequences of soil cover degradation, reduction of soil fertility, damage to agricultural crops and, consequently, economic losses. The conducted studies should be used as a basis for the development of soil protective erosion resistance, contour and land development activities and the formation of the concept of sustainable land use in the steppe zone of Ukraine.

\section{REFERENCES}

1. Achasov A.B., Bulyhin S.Yu., Mozheiko T.A. and oth. 2000. Methodic and regulations of recording of effect and hazard of erosion (guidance manual), Kharkiv: 64 p. (in Ukrainian).

2. Bagnold R.A. 1941. The Physics of Blown Sand and Desert Dunes. London, Chapman and Hall: 265 p.

3. Baliuk S.A., Medvediev V.V., Miroshnychenko M.M., Skrylnik Ye.V., Tymchenko D.O., Fatieiev A.I., Khrystenko A.O., Tsapko Yu.L., 2012. Ecological condition of soils of Ukraine. Ukrainian geographical magazine, No.2: 38-42. (in Ukrainian).

4. Baliuk S.A., Tymchenko D.O., Hychka M.N. and oth. 2010. Scientific and applied foundations of protection of soils against erosion in Ukraine: monograph. Edited by S.A. Baliuk and L.L. Tovazhnianskyi. Kharkiv: NTU “KPI”: 460 p. (in Ukrainian).

5. Benkobi L., Trlica M.J., Smith J.L. 1994. Evaluation of a refined surface cover subfactor for use in RUSLE. Range Manage, Vol. 47: 74-78.

6. Biesemans J., Meirvenne M.V., Gabriels D. 2000. Extending the RUSLE with the Monte Carlo error propagation technique to predict long-term average off-site sediment accumulationSoil Water Conserv, Vol. 55: 35-42.

7. Bulyhin S.U. 2005. Formation of ecologically resistant agrolandscapes. Kyiv: Urozhai: 300 p. . (in Ukrainian).

8. Chepil W.S. 1950. Properties of soil which influence wind erosion. I. The governing principle of surface roughness. Soil Sci., 69: 149-162 
9. Chi W., Zhao Y., Kuang W., He H. 2019. Impacts of anthropogenic land use/cover changes on soil wind erosion in China. Science of the Total Environment, Vol. 668: 204-215

10. Chornyi S.H., Chorna T.M. 2000. Reasons and consequence of dust storm of March 23-24, 2017. Regional problems of Ukraine: Geographical analysis and search of solutions. Kherson: PE Vyshemyrskyi: http://ekhsuir.kspu.edu/handle/123456789/5306 (in Ukrainian).

11. Conception of soil protection against erosion in Ukraine. 2008. Edited by S.A. Baliuk and L.L. Tovazhnianskyi. Kharkiv: NSC "Institute for soil science and agrochemistry”: 53 p. (in Ukrainian).

12. Dehodiuk Ye.H. 2015. Basin approach in biogeocenosis and agrarian sphere in the context of development of farming system in XXI century. Farming. No.2 (889): 21-24. (in Ukrainian).

13. Dudiak N.V., Pichura V.I., Potravka L.A., Stratichuk N.V. 2019. Geomodelling of Destruction of Soils of Ukrainian Steppe Due to Water Erosion. Journal of Ecological Engineering. Vol. 20, Iss. 8.: 192-198.

14. Furdychko O.I. 2014. Ecological fundamentals of balanced development of agrarian sphere in the context of European integration of Ukraine: monograph. Kyiv: DIA:432 p. (in Ukrainian).

15. Furdychko O.I. Stadnyk A.P. 2012. Fundamentals of management of agrolandscapes of Ukraine. Kyiv: Argarian science:384 p. (in Ukrainian).

16. Guo Q., Cheng C., Jiang H., Liu B., Wang Y. 2019. Comparative rates of wind and water erosion on typical farmland at the northern end of the Loess Plateau, China. Geoderma, Vol. 352: 104-115.

17. Jiang Ch., Zhang H., Zhang Zh., Wang D. 2019. Model-based assessment soil loss by wind and water erosion in China's Loess Plateau: Dynamic change, conservation effectiveness, and strategies for sustainable restoration. Global and Planetary Change, Vol. 172: 396-413.

18. Lisetskii F., Pichura V. 2016. Steppe Ecosystem Functioning of East European Plain under AgeLong Climatic Change Influence. Indian Journal of Science and Technology, Vol. 9(18): 1-9. DOI: 10.17485/ijst/2016/v9i18/93780.

19. Lisetskii F.N., Matsibora A.V., Pichura V.I. 2016. Reconstruction of paleoclimatic conditions of the second half of the Holocene on the results of the study of buried and floodplain soils in the south of the East European Plain. International Journal of Environmental Problems, Vol. 4 (2.): 131-148. DOI: $10.13187 /$ ijep.2016.4.131

20. Lisetskii F.N., Pavlyuk Ya.V., Kirilenko Zh.A., Pichura V.I. 2014. Basin organization of nature management for solving hydroecological problems. Russian Meteorology and Hydrology. Vol. 39 (8): 550-557.
21. Luo W., Zhao W., Zhuang Y. 2018. Sand-burial and wind erosion promote oriented-growth and patchy distribution of a clonal shrub in dune ecosystems. CATENA, Vol. 167: 212-220

22. Lysetskyi F.N., Svetlychnyi A.A., Chornyi S.H. 2012. Modern issues of erosion science. Edited by Svetlychnyi A.A. Bilhorod: Konstanta: 456 p. (in Russian).

23. Mozheiko H.A., Moskalenko V.M., Bulyhin S. Yu., Tymchenko D.O.,Lavrovskyi A.B., Kanash A.P., 1980. Prediction of possible soil loss due to wind erosion in the steppe zone of Ukraine. Kharkiv: ISA named after A.N. Sokolovskyi: 83 p. (in Russian).

24. Pichura V.I. 2016.Spatial prediction of soil erosion risk in the Dnieper river basin using revised universal soil loss equation and GIS-technology. Вісник Житомирського національного агроекологічного університету. No 2(56) т.1:С. 3-11.

25. Pichura V.I. 2017. Zonal patterns of age changes in climate of the territory of Dnipro basin. Dnipropetrovsk State Agrarian and Economic University, No. 2:43-45 p. (in Ukrainian).

26. Pichura V.I., Domaratsky Y.A., Yaremko Yu.I., Volochnyuk Y.G., Rybak V.V. 2017. Strategic Ecological Assessment of the State of the Transboundary Catchment Basin of the Dnieper River Under Extensive Agricultural Load. Indian Journal of Ecology, Vol. 44 (3): 442-450.

27. Poręba G., Śnieszko Z., Moska P., Mroczek P. 2019. Deposits of Neolithic water soil erosion in the loess region of the Małopolska Upland (S Poland) - A case study of the settlement micro-region in Bronocice. Quaternary International, Vol. 502, Part A: 45-59

28. Sameni A., Moosavi A., Mahmoodabadi M., Laurent B. 2019. Portable wind tunnel experiments to study soil erosion by wind and its link to soil properties in the Fars province, Iran. Geoderma, Vol. 333: 69-80

29. Scientific and applied fundamentals of soil protection against erosion in Ukraine: monograph. 2010. Edited by S.A. Baliuk and L.L. Tovazhnianskyi. Kharkiv: NTU "KPI": 460 p. (in Ukrainian).

30. Shahaev V.L. 2004 Modification of soil protection technologies against wind erosion through designing thatcherizer of couch grass: Dissertation .... Cand. of Tech. Scien.: 05.20.01:Ulan-Ude: 159 p. (in Russian).

31. Shvebs H.I. 1985. Contour farming. Odesa: Maiak: 55 p. (in Russian).

32. Shvebs H.I., Antonova S.O., Ihoshyna V.I., Tsurkan O.I., Esaulov H.I., Ihoshyn M.I. 2003. Protection of soils against erosion destruction in river and water reservoir basin of Ukraine. Bulletin of ONU, Vol. 5(8):116-128p. (in Ukrainian).

33. Sytnyk V.P., Bezyhlyi M.D., Melnyk S. I. and others. 
2008 Conception of soil protection against erosion in Ukraine. Kharkiv: 59 p. (in Ukrainian).

34. Tarariko O.H., Kuchma T.L., Ilienko T.V., Demiakiuk O.S. 2017. Erosion degradation of soils of Ukraine under the influence of climate changes. Agroecological journal, No.1: 7-15. (in Ukrainian).

35. Tarariko O.H.,Moskalenko V.M. 2002. Catalogue of activities on optimization of structure of agrolandscapes and soil protection against erosion. Kyiv: Fitosotsiotsentr: 64 p. (in Ukrainian).

36. Van Leeuwen WJD, Sammons G 2004. Vegetation dynamics and soil erosion modeling using remotely sensed data (MODIS) and GIS. Tenth Biennial USDA Forest Service Remote Sensing Applications Conference, 5-9 April 2004, Salt Lake City, UT. US Department of Agriculture Forest Service Remote Sensing Applications Center, Salt Lake City.
37. Voloshchuk M.D. 2016. Erosion degradation of chernozems of southern-western part of Ukraine and Republic of Moldova. Bulletin of Dnipro State Agrarian and Economic University, 4 (24): 41-51. (in Ukrainian).

38. Voloshchuk M.D., Petrenko N.I., Yatsenko S.V. 2014. Scientific and applied fundamentals of protection of soils against erosion in Ukraine: monograph. Erosion of soils in Ukraine: evolution, theory and practice. Kyiv: 327 p. (in Ukrainian).

39. Yhoshyn N.I. 1996. Characteristic of erosion and deflation processes in Ukraine. Collection of reports of anniversary scientific and technical conference "DonSTU - 75 years":113-125 p. (in Russian).

40. Zingg A.W. 1953. Wind tunnel studies of the movement of sedimentary material. Lowa State Univ. Proc. 5th Hydraulic Conf. Bull., 34: 111-135 